\title{
Influence of light and temperature on seed germination of Cereus pernambucensis Lemaire (Cactaceae)
}

\author{
Fábio Socolowski, ${ }^{1,3}$ Daniela Cristine Mascia Vieira ${ }^{2}$ Edson Simão ${ }^{2}$ \& Massanori Takaki ${ }^{2}$ \\ ${ }^{1}$ Departamento de Produção Vegetal, Escola Superior de Agricultura Luiz de Queiroz-ESALQ, \\ Universidade de São Paulo - USP, \\ Av. Pádua Dias, 11, CP 9, CEP 13418-900, Piracicaba, SP, Brazil \\ ${ }^{2}$ Departamento de Botânica, Universidade Estadual Paulista Júlio de Mesquita Filho - UNESP, \\ Av. 24 A, 1515, CP 199, CEP 13506-900, Rio Claro, SP, Brazil \\ ${ }^{3}$ Corresponding author: Fábio Socolowski,e-mail: fsocolowski@yahoo.com.br
}

SOCOLOWSKI, F., VIEIRA, D.C.M., SIMÃO, E. \& TAKAKI, M. Influence of light and temperature on seed germination of Cereus pernambucensis Lemaire (Cactaceae). Biota Neotrop. 10(2): http://www.biotaneotropica. org.br/v10n2/en/abstract?article+bn00710022010.

\begin{abstract}
The objective of the present study was to evaluate the effects of light and temperature on germination of Cereus pernambucensis seeds, a species of columnar cactus native to Brazil and naturally incident in the restinga. Cereus pernambucensis seeds were incubated under different temperatures, from 5 to $45{ }^{\circ} \mathrm{C}$, with $5{ }^{\circ} \mathrm{C}$ intervals, and under alternating temperatures of $15-20{ }^{\circ} \mathrm{C}, 15-30{ }^{\circ} \mathrm{C}, 20-25{ }^{\circ} \mathrm{C}, 20-30{ }^{\circ} \mathrm{C}, 20-35{ }^{\circ} \mathrm{C}, 25-30{ }^{\circ} \mathrm{C}$, 25-35 ${ }^{\circ} \mathrm{C}$, and $30-35^{\circ} \mathrm{C}$, both under continuous white light and dark. The seeds were also incubated in a gradient of phytochrome photoequilibrium at $25^{\circ} \mathrm{C}$. The highest percentage germination in this species was between 25 and $30^{\circ} \mathrm{C}$. The minimum temperature was between 15 and $20^{\circ} \mathrm{C}$ and the maximum between 35 and $40^{\circ} \mathrm{C}$. Alternating temperatures did not affect the percentage of seed germination, but it did alter the rate and synchronization indexes. Seeds incubated in the dark did not germinate under any of the conditions tested, indicating that this species when cultivated present light sensitive seeds controlled by phytochrome. The seeds can tolerate a lot of shade conditions, germinating under very low fluence response of phytochrome.
\end{abstract}

Keywords: columnar cacti, Cereus pernambucensis, restinga.

SOCOLOWSKI, F., VIEIRA, D.C.M., SIMÃO, E. \& TAKAKI, M. Influência da luz e da temperatura na germinação de sementes de Cereus pernambucensis Lemaire (Cactaceae). Biota Neotrop. 10(2): http://www. biotaneotropica.org.br/v10n2/pt/abstract?article+bn00710022010.

Resumo: Este estudo teve como objetivos avaliar os efeitos da luz e da temperatura na germinação de sementes de Cereus pernambucensis, espécie de cacto colunar, nativa do Brasil que ocorre naturalmente na restinga. As sementes foram incubadas sob diferentes isotermas, entre 5 e $45^{\circ} \mathrm{C}$, com intervalos de $5^{\circ} \mathrm{C}$, e sob termoperíodos de $15-20^{\circ} \mathrm{C}, 15-30{ }^{\circ} \mathrm{C}, 20-25^{\circ} \mathrm{C}, 20-30{ }^{\circ} \mathrm{C}, 20-35^{\circ} \mathrm{C}, 25-30{ }^{\circ} \mathrm{C}, 25-35^{\circ} \mathrm{C}, 30-35^{\circ} \mathrm{C}$, ambos na presença e ausência de luz contínua. As sementes também foram submetidas a um gradiente de fotoequilíbrio do fitocromo a $25^{\circ} \mathrm{C}$. A temperatura ótima para a germinação desta espécie está entre 25 e $30^{\circ} \mathrm{C}$. A alternância de temperatura não alterou a porcentagem de sementes germinadas, porém observaram-se alterações na velocidade e índice de sincronização. As sementes incubadas no escuro não germinaram em qualquer das condições testadas, indicando que a espécie, quando em condições de cultivo, é fotoblástica positiva. As sementes apresentam tolerância a diversas condições de sombreamento, germinando em condições de fluência muito baixa.

Palavras-chave: cacto colunar, Cereus pernambucensis, restinga. 


\section{Introduction}

The Cactaceae with approximately 1.500 to 2.000 species is almost exclusively found on the American continent. Incidence is from northern Canada to the Argentinean Patagonia, ranging from arid and semi-arid regions to temperate, subtropical and tropical forests, where some species like epiphytes may occur (Bravo-Hollis $\&$ Scheinvar 1995).

Cereus pernambucensis is a species of colunar cactus native of Brazil (Lachance et al. 2001) and naturally incident in the "Restinga" (Kelecom et al. 2002). It is prominent in ground vegetation of mobile and semi-fixed dunes and also occurs in fixed dunes where vegetation is low with dense bushes (Rizzini 1997). Fruits of this plant are edible and used in preparing jelly and juice (Kelecom et al. 2002).

The effect of light on seed germination in this family is well known. Some species require light for germination at near optimum temperatures and some species are indifferent to light under these conditions (Benítez-Rodrígues et al. 2004). Furthermore, Rojas-Aréchiga et al. (1997) related the necessity of light for germination to cactus type of life form. Barrel type cacti need light, and columnar type cacti are indifferent to light. Benítez-Rodrígues et al. (2004) believed that columnar cacti species can present varied responses to light and that this fact may be related to the geographic distribution of the species or to its phylogenic origin.

According to Andrade (1995), light and temperature are the main factors that promote germination in soils with good water availability. Temperature may also determine the amount of dormant seeds in a population while concurrently modulating germination of nondormant seeds (Benech-Arnold \& Sánchez 1995).

For many plant species in arid environments, alternating temperatures may substitute the necessity of light for seed germination (Benítez-Rodrígues et al. 2004). In agreement with Pons (2000) and Probert (2000), fluctuating temperatures may induce germination in the dark, since this fluctuation may interfere in the production of the active phytochrome form. Few studies have evaluated the effect of alternating temperature and dark on germination in Cactaceae species (Benítez-Rodrígues et al. 2004).

According to Smith (1975), the phytochrome is responsible for germination in light sensitive seeds. Furthermore, Takaki (2001) considered that all seeds possess phytochrome; however, those that germinate as much in the light as in the dark present phytochrome A and those that germinate only in the light contain phytochrome B.

Open environments not only have a greater availability of light, but they also have greater thermal range (Bullock 2000). In the "Restinga", average minimum temperature of the soil surface under tree canopy is $21.5^{\circ} \mathrm{C}$, which is similar to those observed in open areas exposed to the sun $\left(21^{\circ} \mathrm{C}\right)$. On the other hand, the average maximum temperature in these areas is $45.9{ }^{\circ} \mathrm{C}$, which is much greater than those observed in shaded areas $\left(28.3{ }^{\circ} \mathrm{C}\right.$ ) (Pinheiro \& Borghetti 2003).

The objective of the present study was to evaluate the effects of light, temperature, alternating temperatures as well as theoretical photoequilibrium of the photochrome on germination of Cereus pernambucensis Lemaire seeds.

\section{Materials and Methods}

Open Cereus pernambucensis Lemaire fruits were collected from cultivated bushes at full sun in the Experimental Garden of Rio Claro Campus (São Paulo State, Brazil), in November, 2005. Fruits were washed in running water over a sieve to remove the pulp. Seeds were dried in a non-controlled environment and subsequently stored in glass containers at $10 \pm 1{ }^{\circ} \mathrm{C}$ until initiation of the experiments. The effects of temperature and light on germination were obtained in a germination chamber (FANEM and MARCONI) at the Laboratory of Plant Photomorphogenesis of the Department of Botany (UNESP/ Rio Claro Campus).

The effect of phytochrome photoequilibrium on germination was carried out in agreement with Suhagara \& Takaki (2004) in a temperature controlled room at $25 \pm 2{ }^{\circ} \mathrm{C}$. Theoretical phytochrome photoequilibrium was calculated according to Mancinelli (1994).

For germination experiments, $50 \mathrm{~mm}$ diameter Petri dishes lined with two sheets of filter paper were used throughout. Each treatment contained four replicates of thirty seeds. Eight treatments of different temperatures at $5{ }^{\circ} \mathrm{C}$ intervals from 5 to $45{ }^{\circ} \mathrm{C}$ were used to evaluate the effect of different isotherms under white light or dark on germination. The effect of the 12 hours thermal period on germination was tested with the following pairs of alternating temperatures: $15-20{ }^{\circ} \mathrm{C}, 15-30{ }^{\circ} \mathrm{C}, 20-25{ }^{\circ} \mathrm{C}, 20-30{ }^{\circ} \mathrm{C}, 20-35{ }^{\circ} \mathrm{C}$, 25-30 ${ }^{\circ} \mathrm{C}, 25-35^{\circ} \mathrm{C}$ and $30-35^{\circ} \mathrm{C}$ under light and dark. Temperatures and thermal periods that did not allow germination twenty days after the beginning of the experiments were excluded from statistical analyses. The white light was obtained from two fluorescent daylight type $15 \mathrm{~W}$ light bulbs $\left(32.85 \mu \mathrm{mol} . \mathrm{m}^{-1} / \mathrm{s}\right)$. Petri dishes were inserted inside a colorless gerbox container for the experiments in light and a black gerbox container for those in the dark. The seeds under dark condition were monitored with a green safety light (Amaral-Baroli \& Takaki 2001).

Seeds that presented a primary root with at least $1 \mathrm{~mm}$ were considered as germinated. Experiments were monitored daily with counting and removal of germinated seeds. Treatments were ended when the germination was not observed along five consecutive days.

Germination percentage, average germination rate, and synchronization index were calculated according to Labouriau (1983). Analysis of variance (ANOVA) and Tukey test at $\alpha=0.05$ were conducted when variances were normal and homogeneous. These analysis were done on STATISTICA Program. Germination percentage data were transformed into co-sign square roots, and germination rate data were transformed into roots when needed to fulfill the requirements of ANOVA. When original or transformed data were not normal or homogeneous, they were submitted to a Kruskal-Wallis test at $\alpha=0.05$ followed by a Nemenyi test at $\alpha=0.05$ (Zar 1999).

\section{Results and Discussion}

Germination of Cereus pernambucensis Lemaire seeds incubated under different isotherms only occurred at $20,25,30$ and $35^{\circ} \mathrm{C}$ in the light. The highest percentage of germination was observed at 25 and $30{ }^{\circ} \mathrm{C}(100 \%)$; however, these percentages did not significantly differ from temperatures 20 and $35^{\circ} \mathrm{C}$ (Table 1).

Table 1. Effects of different isotherms on percentage, rate and synchronization of germination of Cereus pernambucensis Lemaire seeds.

\begin{tabular}{crccccc}
\hline $\begin{array}{c}\text { Temperature } \\
\left({ }^{\circ} \mathbf{C}\right)\end{array}$ & $\begin{array}{c}\text { Germination } \\
(\boldsymbol{\%})\end{array}$ & \multicolumn{2}{c}{$\begin{array}{c}\text { Rate } \\
\left(\mathbf{d a y}^{-1}\right)\end{array}$} & $\begin{array}{c}\text { Synchronization } \\
\text { index (U) }\end{array}$ \\
\hline 20 & 99.16 & $\mathrm{a}$ & 0.082 & $\mathrm{~b}$ & 3.128 & $\mathrm{a}$ \\
25 & 100.00 & $\mathrm{a}$ & 0.150 & $\mathrm{a}$ & 2.290 & $\mathrm{~b}$ \\
30 & 100.00 & $\mathrm{a}$ & 0.130 & $\mathrm{a}, \mathrm{b}$ & 2.702 & $\mathrm{a}, \mathrm{b}$ \\
35 & 85.83 & $\mathrm{a}$ & 0.090 & $\mathrm{a}, \mathrm{b}$ & 3.160 & $\mathrm{a}$ \\
\hline
\end{tabular}

Percentage and rate data were analyzed by the Kruskal-Wallis and Nemenyi tests. Synchronization data were submitted to ANOVA and Tukey tests. Means with similar letters in a column are not significantly different $(\mathrm{p}>0.05)$. 
Optimum temperature for germination of this species ranged between 25 and $35^{\circ} \mathrm{C}$, since there were no statistically significant differences among germination percentages, although some of them differ on synchronization index at these temperatures. On the other hand, $50 \%$ of seeds from three other species of columnar cacti native to México, Pachycereus hollianus (Weber) Buxd., Cephalocereus chrysacanthus (Weber) Britton \& Rose, and Neobuxbaumia tetetzo var. tetezo (Coult.) Backeb., germinated at temperatures between 15 and $30^{\circ} \mathrm{C}$ as well as at extreme temperatures of 10 and $40{ }^{\circ} \mathrm{C}$, although showing low percentages of germination (Rojas-Aréchiga et al. 1998). Lower temperatures led to lower germination in Pachycereus hollianus seeds (Flores \& Briones 2001).

Results of the present study are in accordance to Alcorn \& Kurtz (1959) and Dau \& Labouriau (1974) who considered that the germination of cactus seeds is stimulated by temperatures between 17 and $34{ }^{\circ} \mathrm{C}$ and $25^{\circ} \mathrm{C}$ is frequently the optimum temperature for germination.

High percentages (94.5\%) of Cereus jamacaru P. DC. seeds also germinated at non-controlled room temperatures $\left(28-30{ }^{\circ} \mathrm{C}\right)$, although only $1.5 \%$ seeds germinated in the dark (Prisco, 1966), which was not observed in Cereus pernambucensis seeds.

Alternate temperatures had no effect on germination. On the other hand, statistically significant differences were observed in the rate and the synchronization of germination (Table 2). According to Rojas-Aréchiga et al. (1997), fluctuations in temperature that normally occur in arid environments may present strong interactions in some photoblastic species as a response of their seeds to light. The alternate pair $25-30{ }^{\circ} \mathrm{C}$ resulted in the greatest velocity and synchrony of germination, corroborating temperature data; however, synchrony in this range did not differ from alternations of $25-35^{\circ} \mathrm{C}$, $30-35^{\circ} \mathrm{C}, 20-30{ }^{\circ} \mathrm{C}$ and $20-25^{\circ} \mathrm{C}$. The lowest velocity and synchrony of germination occurred at alternate pair $15-20{ }^{\circ} \mathrm{C}$, although this range did not differ from alternations of $15-30{ }^{\circ} \mathrm{C}$ and $20-35^{\circ} \mathrm{C}$. The germination rate in Stenocereus queretaroensis Weber (Buxbaum) was low at alternate temperatures $15-25^{\circ} \mathrm{C}$ and did not occur when the mean temperature of $10^{\circ} \mathrm{C}$ was used in the thermal combination (De la Barrera \& Nobel 2003). In agreement with Potter et al. (1984), alternate temperature regimes do not increase germination more than that observed at the optimal temperature. Furthermore, germination at $15-20{ }^{\circ} \mathrm{C}$ and $15-30{ }^{\circ} \mathrm{C}$ may indicate that Cereus pernambucensis seeds present thermal dormancy at temperatures equal or low to $15{ }^{\circ} \mathrm{C}$. Besides, alternate temperatures combined with $20^{\circ} \mathrm{C}$ also promoted reduction in rate.

The tested photoequilibrium of the phytochrome had no effect on the percentage of germinated seeds; however, the rate and synchronization of germination were altered, with the lowest rates and synchronizations observed for the lower percentage of phytochrome photoequilibrium (Table 3).

During this experimentation, Cereus pernambucensis seeds did not germinate in the dark. Seeds presented characteristics of a positive photoblastic species, which according to Takaki (2001) possess phytochrome B as the main controlling agent of germination.

Seeds from Pachycereus pringlei (S.Wats.) Britton \& Rose, a cactus species native to Mexico, presented germination higher than $80 \%$ at $25^{\circ} \mathrm{C}$ under diverse wave lengths (blue, red, green and yellow) and even in the dark, indicating a lack of photo dormancy in this species (Nolasco et al. 1996).

Our results demonstrate that high percentages of Cereus pernambucensis seeds may germinate quickly and uniformly under different shade conditions and very low fluence (Mancinelli 1994). The seed germination through very low fluency indicates involvement of photochrome A (Casal \& Sánchez 1998, Takaki 2001). Furthermore, seeds may be exposed to a variety of environmental conditions and
Table 2. Effects of alternating temperature on percentage, rate and synchronization of germination of Cereus pernambucensis Lemaire seeds.

\begin{tabular}{ccccccc}
\hline $\begin{array}{c}\text { Temperature } \\
\left({ }^{\circ} \mathbf{C}\right)\end{array}$ & $\begin{array}{c}\text { Germination } \\
(\%)\end{array}$ & \multicolumn{2}{c}{$\begin{array}{c}\text { Rate } \\
\left(\mathbf{d a y}^{-1}\right)\end{array}$} & $\begin{array}{c}\text { Synchronization } \\
\text { index }(\mathbf{U})\end{array}$ \\
\hline $15-20$ & 94.91 & $\mathrm{a}$ & 0.049 & $\mathrm{f}$ & 3.622 & $\mathrm{a}$ \\
$15-30$ & 98.33 & $\mathrm{a}$ & 0.078 & $\mathrm{~d}, \mathrm{e}$ & 3.216 & $\mathrm{a}, \mathrm{b}, \mathrm{c}$ \\
$20-25$ & 95.00 & $\mathrm{a}$ & 0.090 & $\mathrm{c}, \mathrm{d}$ & 2.795 & $\mathrm{c}, \mathrm{d}$ \\
$20-30$ & 96.66 & $\mathrm{a}$ & 0.097 & $\mathrm{~b}, \mathrm{c}$ & 2.666 & $\mathrm{~d}$ \\
$20-35$ & 95.83 & $\mathrm{a}$ & 0.067 & $\mathrm{e}$ & 3.339 & $\mathrm{a}, \mathrm{b}$ \\
$25-30$ & 97.50 & $\mathrm{a}$ & 0.148 & $\mathrm{a}$ & 2.581 & $\mathrm{~d}$ \\
$25-35$ & 95.83 & $\mathrm{a}$ & 0.096 & $\mathrm{~b}, \mathrm{c}$ & 2.794 & $\mathrm{c}, \mathrm{d}$ \\
$30-35$ & 95.00 & $\mathrm{a}$ & 0.111 & $\mathrm{~b}$ & 3.023 & $\mathrm{~b}, \mathrm{c}, \mathrm{d}$ \\
\hline
\end{tabular}

Percentage germination, rate and synchronization were submitted to ANOVA and Tukey tests. Means with similar letters in a column are not significantly different $(\mathrm{p}>0.05)$.

Table 3. Effects of photoequilibrium of the phytochrome on the percentage, rate and synchrony of germination in Cereus pernambucensis Lemaire seeds.

\begin{tabular}{ccccccc}
\hline $\begin{array}{c}\text { Photoequilibrium of } \\
\text { the phytochrome }(\phi)\end{array}$ & $\begin{array}{c}\text { Germination } \\
(\%)\end{array}$ & $\begin{array}{c}\text { Rate } \\
\left.\text { day }^{-1}\right)\end{array}$ & $\begin{array}{c}\text { Synchronization } \\
\text { index }(\mathbf{U})\end{array}$ \\
\hline 0.03 & 88.33 & a & 0.108 & b & 3,184 & b \\
0.17 & 94.16 & a & 0.149 & a & 2,614 & a \\
0.31 & 98.33 & a & 0.156 & a & 2,452 & a \\
0.44 & 98.33 & a & 0.167 & a & 2,237 & a \\
0.54 & 98.33 & a & 0.158 & a & 2,371 & a \\
\hline
\end{tabular}

Percentages were analyzed by the Kruskal-Wallis and Nemenyi tests. Rate and synchronization data were submitted to ANOVA and Tukey tests. Means with similar letters in a column are not significantly different $(\mathrm{p}>0.05)$.

except under complete darkness the seeds of Cereus pernambucensis germinate due to action of phytochrome A and B.

Sandy soils present higher light transmission with longer wavelengths (Pons 2000). This characteristic of sandy soils allows Cereus pernambucensis seeds to germinate even when buried in the restinga. This effect could be much more accentuated during the rainy season, when R:FR ratio and light transmission are favorable in humid, sandy soils, and shorter wavelengths may promote germination in seeds buried close to the soil surface (Rojas-Aréchiga et al. 1997).

According to Benítez-Rodrígues et al. (2004), a requirement of light for germination indicates that only those seeds near the soil surface will be able to germinate, since the quality and quantity of light under the soil influence the Pr:Pfr phytochrome ratio in seeds, thereby inhibiting or promoting germination. In addition, some seeds buried in the soil are extremely sensitive. Sometimes only a few milliseconds of light exposure are enough for germination to occur (Smith 2000) due to phytochrome A (Botto et al. 1996).

This may explain the tolerance of Cereus pernambucensis to the various conditions of temperature, light and shade, as an adaptive condition of the species for recruiting its seedlings in natural environments. In this case, the fact that the seeds were not collected from a wild population becomes relevant. Rojas-Aréchiga et al. (2001) tested germination in wild and cultivated populations of Stenocereus stellatus (Pfeiffer) Ricobbono. They observed greater vigor in cultivated seeds compared to the wild population, with no observed alterations in their photoblastic characteristics.

In addition, specific agents may exist to disperse cacti species in certain natural environments (Moore 2002). According to Steenbergh 
\& Lowe (1969), germination of Cereus giganteus Engelm. [Carnegiea gigantea (Engelm.) Britt. and Rose] may drastically decrease primarily due to the high removal of seeds by animals and low water availability. According to Valiente-Banuet \& Ezcurra (1991), establishment of cacti species by seeds is infrequent and sporadic, limited to years in which the growth season is lasting and places that are "safe", such as the shade of bushes or rocks, which present sufficient humidity for seed germination and protect seedlings against excessive radiation.

\section{Acknowledgements}

The authors are grateful to CNPq for the fellowships. This work was supported by the grants from the CNPq, FAPESP and FUNDUNESP.

\section{References}

ALCORN, S.M. \& KURTZ, E.B. 1959. Some factors affecting the germination of seed of the saguaro cactus (Carnegiea gigantea). Am. J. Bot. 46(7):526-529.

AMARAL-BAROLI, A. \& TAKAKI, M. 2001. Phytochrome controls achene germination in Bidens pilosa L. (Asteraceae) by very low fluency response. Braz. Arch. Biol. Technol. 44(2):121-124.

ANDRADE, A.C.S. 1995. Efeito da luz e da temperatura na germinação de Leandra breviflora Cong., Tibouchina benthamiana Cong., Tibouchina grandifolia Cong. e Tibouchina moricandia (DC.) Baill. (Melastomataceae). Rev. Bras. Sementes 17:29-35.

BENECH-ARNOLD, R.L. \& SÁNCHEZ, R.A. 1995. Modeling weed seed germination. In Seed development and germination (J. Kigel \& G. Galili, eds.). Dekker, New York, p. 545-566.

BENÍTEZ-RODRÍGUES, J., OROZCO-SEGOVIA, A. \& ROJASARÉCHIGA, M. 2004. Light effect on seed germination of four Mammillari species from the Tehuacán-cuicatlán valley, central Mexico. Southwest. Nat. 49(1):11-17.

BOTTO, J.F., SÁNCHEZ, A., WHITELAM, G.C. \& CASAL, J.J. 1996. Phytochrome A mediates the promotion of seed germination by very low fluences of light and canopy shade light in Arabidopsis. Plant Physiol. 110(2):439-444.

BRAVO-HOLLIS H. \& SCHEINVAR, L. 1995. El Interesante mundo de las cactaceas. UNAM-Fondo de Cultura, DF, Mexico, 233p.

BULLOCK, J.M. 2000. Gaps and seedling colonization. In Seeds: the ecology of regeneration in plant communities (M. Fenner ed.). CABI, London, p. 375-395.

CASAL, J.J. \& SÁNCHEZ, R.A. 1998. Phytochromes and seed germination. Seed Sci. Res. 8:317-329.

DAU, L. \& LABOURIAU, L.G. 1974. Temperature control of seed germination in Pereskia aculeate Mill. An. Acad. Bras. Cienc. 46(2):311-322.

DE LA BARRERA, E. \& NOBEL, P.S. 2003. Physiological ecology of seed germination for the columnar cactus Stenocereus queretaroensis. J. Arid Environ. 53(3):297-306.

FLORES, J. \& BRIONES, O. 2001. Plant life-form and germination in a Mexican Inter-tropical desert: effects of soil water potential and temperature. J. Arid Environ. 47(4):485-497.

KELECOM, A., REIS, G.L., FEVEREIRO, P.C.A., SILVA, J.G., SANTOS, M.G., MELLO NETO, C.B.M., GONZALEZ, M.S., GOUVEA, R.C.S. \& ALMEIDA, G.S.S. 2002. A multidisciplinary approach to the study of the fluminense vegetation. An. Acad. Bras. Cienc. 74(1):171-181.

LABOURIAU, L.G. 1983. A germinação das sementes. Secretaria-Geral da OEA, Washington, 174p.
LACHANCE, M., STARMER, W.T., ROSA, C.A., BOWLES, J.M., BARKER, J.S.F. \& JANZEN, D.H. 2001. Biogeography of the yeast of ephemeral flowers and their insects. FEMS Yeast Research 1(1):1-8.

MANCINELLI, A.L. 1994. The physiology of phytochrome action. In Photomorphogenesis in plants (R.E. Kendrick \& G.H.M. Kronenberg, eds.). Kluwer Academic Publishers, The Netherlands, p. 211-269.

MOORE, P.D. 2002. Express delivery by bat. Nature 420(6911):34-35.

NOLASCO, H., VEGA-VILLASANTE, F., ROMERO-SCHMIDT, H.L. \& DIAZ-RONDERO, A. 1996. The effects of salinity, acidity, light and temperature on the germination of seeds of cardón (Pachycereus pringlei (S.Wats.) Britton \& Rose, Cactaceae). J. Arid Environ. 33(1):87-94.

PINHEIRO, F. \& BORGHETTI, F. 2003. Light and temperature requirements for germination of seeds of Aechmea nudicaulis (L.) Griesebach and Streptocalyx floribundus (Martius ex Schultes F.) Mez (Bromeliaceae). Acta Bot. Bras. 17(1):27-35.

PONS, T.L. 2000. Seed responses to light. In Seeds: the ecology of regeneration in plant communities (M. Fenner, ed.). CABI, London, p. 237-260.

POTTER, R.L., PETERSEN, J.L. \& UECKERT, N. 1984. Germination responses of Opuntia spp. to temperature, scarification and other seed treatments. Weed Sci. 32:106-110.

PRISCO, J.T. 1966. Action of light on mandacaru seed germination. Rev. Bras. Biol. 26:261-262.

PROBERT, R.J. 2000. The role of temperature in the regulation of seed dormancy and germination. In Seeds: the ecology of regeneration in plant communities (M. Fenner, ed.). CABI, London, p. 261-292.

RIZZINI, C.T. 1997. Tratado de fitogeografia do Brasil: aspectos ecológicos, sociológicos e florísticos. Âmbito Cultural Edições Ltda, Rio de Janeiro, $747 \mathrm{p}$.

ROJAS-ARÉCHIGA, M., CASAS, A. \& VÁZQUEZ-YANES, C. 2001. Seed germination of wild and cultivated Stenocereus stellatus (Cactaceae) from the Tehuacán-Cuicatlán Valley, Central México. J. Arid Environ. 49(2):279-287.

ROJAS-ARÉCHIGA, M., OROZCO-SEGOVIA, A. \& VÁZQUEZ-YANES, C. 1997. Effect of light on germination of seven species of cacti from the Zapotitlán Valley in Puebla, México. J. Arid Environ. 36(4):571-578.

ROJAS-ARÉCHIGA, M., VÁZQUEZ-YANES, C. \& OROZCO-SEGOVIA, A. 1998. Seed response to temperature of Mexican cacti species from two life forms: an ecophysiological interpretation. Plant ecol. 135(2):207-214.

SMITH, H. 1975. Phytochrome and Photomorphogenesis: an introduction to the photocontrol of plant development. Mc Graw Hill Company, London, New York, 220p.

SMITH, H. 2000. Phytocrome and light signal perception by plants - an emerging synthesis. Nature 407(6804):585-591.

STEENBERGH, W.F. \& LOWE, C.H. 1969. Critical factories during the first years of life sauaro (Cereus giganteus) as Saguaro National Monument, Arizona. Ecology 50:825-834.

SUGAHARA, V.Y. \& TAKAKI, M. 2004. Effect of light and temperature on seed germination in guava (Psidium guajava L. - Mytaceae). Seed Sci. Technol. 32(3):759-764.

TAKAKI, M. 2001. New proposal of classification of seed based on forms of phytochrome instead of photoblastism. Rev. Bras. Fisiol. Veg. 13(1):103-107.

VALIENTE-BANUET, A. \& EZCURRA, E. 1991. Shade as a cause of the association between the cactus Neobuxbaumia tetetzo and the nurse plant Mimosa luisana in the Tehuacán valley, Mexico. J. Ecol. 79:961-971.

ZAR, J.H. 1999. Biostatiscal analysis. Prentice Hall, New Jersey, 663p.

Received 15/10/09

Revised 07/03/10

Accepted 13/04/10 